\title{
INKULTURASI PRIER
}

\section{MEMPERKAYA EKSPRESI IMAN DENGAN MUSIK}

\author{
Simon Arief Herdian Putra Tama ${ }^{a, 1}$ \\ a Universitas Sanata Dharma, Yogyakarta, Indonesia \\ ${ }^{1}$ sahputratama@gmail.com.
}

\section{Kata-kata Kunci:}

inkulturasi, indonesianisasi, post-kolonial, iman dan budaya, karl-edmund prier, madah bakti

\begin{abstract}
ABSTRAKSI
Post-colonial studies present a critique that the Church cannot exist merely as an archaic relic of colonialism. To transform this poignant stereotype, the Church should engage an inculturation. As a man of the Church, Karl-Edmund Prier has been involved in the Church's inculturation projects by placing himself in the middle of the tension between faith and culture. His major contribution is the inculturated liturgical music to enrich the local Church's creedal expression. He initiated an inculturation process, representing the willingness of the "universal" to enter into the "local", an effort done with humility and kenosis. Through his method, Prier endeavored to discover liturgical songs that were harmonious with the sitz im leben, local sense, and the cultural imagination of the national Indonesian government. His monumental work is Madah Bakti considered as a mimicry of Gotteslob. As a liturgical musical book of the Indonesian Church, it represents a mixture of western and Indonesian ethnic songs. The aim is to allow the faithful to experience the local Church collaborates with the universal Church. Prier conducts simultaneously two acts,

holding the global locally and promoting the local globally.
\end{abstract}

\section{PENDAHULUAN}

Imajinasi kolektif Gereja Katolik Indonesia dapat dibayangkan lewat lagu-lagu Madah Bakti (1980). Sebagai eksperimen inkulturasi Konsili Vatikan II, Madah Bakti yang dikerjakan oleh Prier, S.J. menjadi salah satu elemen yang turut membangun identitas Gereja Katolik Indonesia. Identitas tersebut semakin kuat dengan saling dikenalnya lagu-lagu daerah dari suku-suku di Indonesia. Sebagai contoh, gending lagu "Raja Agung" (Nata Agung) yang bercorak Jawa ternyata dapat diterima oleh Gereja Flores. Dengan menyanyikan "Raja Agung", umat Flores bisa turut merasakan (Jawa: greng) ekspresi Kristus sebagai Raja Semesta Alam. ${ }^{1}$

Sayangnya saat ini banyak orang lebih tertarik mengembalikan ekspresi musik Gereja ke Barat. Entah karena pengaruh modernisme, sekularisme, fundamentalisme atau sekadar untuk menunjukkan identitas kekristenan dengan bergaya kebaratbaratan. Padahal, proyek inkulturasi merupakan perjuangan panjang Gereja Indonesia. Sejak zaman sebelum Konsili Vatikan II, saat istilah inkulturasi belum dipopulerkan, banyak tokoh-tokoh seperti Hardjasoebrata, Mgr. Soegijapranata, Mgr, Willhelmus van Bekkum sudah mengerjakan proyek musik inkulturasi secara grass roots. Hal ini dilakukan mengingat kekristenan dipandang 
sebagai barang asing, antek kolonial ${ }^{2}$. Maka usaha pengakaran iman kristiani di Jawa, Flores, Timor merupakan perkara penting.

Gallagher menuturkan perjumpaan iman dan budaya kerap menimbulkan benturan kebudayaan. ${ }^{3}$ Di Indonesia hingga kini muncul konflik-konflik budaya di mana agama Katolik dipandang sebagai agama penjajah. Bahkan kajian postkolonial menuduh Gereja melakukan upaya pembaratan (westernisasi) seiring dengan kolonialisasi imperialisme bangsa Eropa. Pasalnya, kristenisasi memang terbukti telah membuat pribumi dibaratkan. ${ }^{4}$ Beberapa pengaruh kultural itu tampak dalam arsitektur Gereja, corak musik, dan manajemen organisasi Gereja.

Tak dapat dipungkiri budaya Barat, kolonialisme dan kristianitas merupakan kesatuan yang hampir tak dapat dipisahkan. Memori historis penjajahan memberi persepsi bahwa orang-orang Barat itu jahat, licik dan kejam sekaligus memiliki konstruksi citra ras unggul, modern dan beradab. Akibatnya, muncul ambivalensi sikap dalam diri pribumi, di satu sisi resisten dengan orang Barat di lain sisi tunduk menerima mereka sebagai pembawa peradaban.

Bertolak dari fenomena kultural tersebut, tulisan ini bertujuan meneliti kompleksitas inkulturasi yang dilakukan oleh Karl Edmund Prier, S.J. Secara sederhana, permasalahan di dalam tulisan ini hendak dirumuskan sebagai berikut: (1) Bagaimana kontekstualisasi musik Liturgi Gereja di Indonesia?, (2) Bagaimana proses kreatif inkulturasi dikerjakan oleh Karl Edmund Prier, S.J.?, (3) Sebagai man of the church bagaimana Karl Edmund Prier, S.J. mengolah dan menghidupi tegangan antara iman dan budaya?

\section{KOMPLEKSITAS INKULTURASI}

Sebelum menjawab ketiga pertanyaan tersebut kita perlu sadar bahwa perjumpaan antara iman dan budaya acapkali menimbulkan benturan-benturan kebudayaan. Edward Said berpendapat bahwa dalam perjumpaan kebudayaan, orang Barat selalu merasa dirinya lebih superior daripada orang
Timur yang menurut mereka inferior. Oleh sebab itu, orang Barat tidak merasa menjajah justru merasa berjuang membantu orang Timur memperoleh keselamatan hidup yang lebih baik. Akibatnya Barat selalu merasa lebih tahu apa yang dibutuhkan Timur daripada orang Timur sendiri. Wacana kolonial tersebut membangun citra orang Eropa lebih unggul dari pada the others (non-Eropa). Pandangan-pandangan yang arbitrer ini menurut Edward Said adalah cara Barat untuk mendominasi, merestrukturisasi dan menguasai Timur. ${ }^{5}$

Demikian halnya dalam misiologi. Lewat gerakan Glory, Gold, Gospel, perjumpaan antar budaya berimbas pada keinginan Gereja untuk mempertobatkan budayabudaya kafir. Kabarnya, Paus Pius IX di L'Osservatore Romano tanggal 24 Februari 1935 menyatakan bahwa Gereja Katolik senantiasa mendukung penjajahan sebab sesuai dengan rencana Tuhan sebagai sarana pemberadaban bangsa primitif. Pada masa itu, Gereja memandang tidak ada keselamatan di luar Gereja (Extra Ecclesiam nulla salus). Implikasinya, muncul klaim superioritas bahwa agama Katolik adalah satu-satunya agama yang benar dan membawa keselamatan. Maka para misionaris terpanggil untuk menyebarkan agama yang benar tersebut kepada bangsa-bangsa primitif kafir. Seruan Mat. 28:19 seolah memobilisasi semangat misioner bangsa Barat untuk membaptis mereka dalam nama Yesus Kristus sang penyelamat seluruh dunia. ${ }^{6}$ Selain itu yang tidak sesuai dengan penyeragaman pemikiran Gereja, dengan mudahnya dikutuk (anathema sit).

Homi Bhabha memperbaiki pemikiran Said tersebut dengan menunjukkan bahwa perjumpaan antar kebudayaan Barat-Timur merupakan suatu kondisi bersama ( $a$ condition of being) yang tidak melulu negatif. Selalu ada ruang ketiga dalam oposisi biner penjajah dan terjajah yang determinis. Bhabha menunjukkan bahwa ruang ketiga adalah sebuah proses ambivalensi. ${ }^{7}$ Jika dalam oposisi biner diumpamakan ada ruang atas dan ruang bawah, ruang ketiga adalah ruang antara (in between). Ruang ketiga atau ruang antara adalah ruang 
liminalitas $^{8}$ di mana pelbagai budaya bercampur dipadupadankan. Ruang ini menjadi perjumpaan interaksi simbolik antara kelompok budaya asing dan pribumi. Oleh sebab itu dalam perjumpaan antara iman dan budaya selalu ada ruang dinamika kreatif sehingga menghasilkan suatu identitas budaya yang baru. Saat kolonialisme tercatat turut menebarkan benih Kristianitas ke Asia, Afrika, dan Amerika. Kegiatan itu melahirkan Gereja-Gereja di tempat baru yang menuntut kegiatan kreatif adaptasi dan akomodasi (inkulturasi) ${ }^{9}$. Di daerah koloni yang memiliki beragam kebudayaan yang berbeda dengan Eropa, para misionaris ditantang untuk bernegosiasi mencari bentuk ekspresi iman bagi orang pribumi. ${ }^{10}$

Tetapi inkulturasi memang problematis. Gereja pada masa kolonialisme lebih menjunjung keseragaman untuk menjaga kesatuan tubuh Gereja Katolik. Gereja merasa wajib memindahkan Gereja yang seragam ini, yang de facto diwarnai kultur Eropa, ke tempat rintisan Kekristenan yang baru. Seluruh tradisi, warisan, konsep, rumusan Gereja Eropa dijadikan norma ukuran bagi Gereja non Eropa. Hal ini pula yang dibawa para misionaris Eropa ke Indonesia pada abad XIX dan XX awal. Gereja turut dalam ekspansi kultural Eropa yang memengaruhi pudarnya kebudayaan pribumi. Saat itu, banyak orang memahami bahwa kebudayaan yang sesuai dengan agama Kristen hanyalah kebudayaan Eropa. ${ }^{11}$ Tentu saja hal ini berimbas pada citra Gereja yang kurang baik di banyak negara non-Eropa sebab berbarengan dengan kolonisasi penjajahan. ${ }^{12}$

Sesudah kolonialisme berakhir, wacana postkolonial muncul sebagai tanggapan terhadap wacana kolonial. Wacana ini menerbitkan kecurigaan dan gugatan atas praktek wacana kolonialisme. ${ }^{13}$ Di negara Indonesia, gugatan tersebut muncul dalam bentuk sikap anti Barat, dan gerakan indonesianisasi/pribumisasi. Identitas Gereja Katolik di Indonesia turut dipermasalahkan. Oleh sebab itu banyak tokoh Katolik muncul untuk terus menerus memaknai slogan lama tapi selalu aktual sejak masa kemerdekaan dari Mgr. Soegijapranata yakni 100\% Katolik $100 \%$ Indonesia.
Senada dengan itu, seruan aggiornamento Konsili Vatikan II membuat Gereja Katolik Indonesia turut bergerak dalam arus kebudayaan inkulturasi. Proyek pribumisasi yang sudah lama dikerjakan beberapa misionaris semakin mendapat maknanya secara resmi sebagai geliat ekspresi Gereja muda. ${ }^{14}$ Konsili Vatikan II mengundang Gereja-Gereja muda untuk menunjukkan inisiatif dan kreativitasnya dalam problem benturan budaya di wilayahnya (AG. 15) termasuk dalam bidang liturgi (SC. 37-40). ${ }^{15}$ Banyak Gereja setempat kemudian berupaya agar identitas mereka tampak Roma sekaligus mengakar dalam budaya setempat. Mengingat urgensi dari masalah inkulturasi, Paus Paulus VI mengajak Gereja untuk serius memperhatikan evangelisasi budaya setempat.

Sebagai peristiwa budaya, Konsili Vatikan II mengajarkan kemendesakan masalah inkulturasi $^{16}$ seperti tampak dalam $A d$ Gentes (art. 9, 10, 11, 21, 22), Gaudium et Spes (art. 44-58), Lumen Gentium (art. 13, 17, 23), Nostra Aetate art. 2 dan Sacrosanctum Concilium art. 37. Konsili Vatikan II memang tidak menggunakan istilah inkulturasi secara langsung. Tetapi Konsili Vatikan II mendorong agar Injil diwartakan melalui pelbagai bentuk pendekatan budaya setempat. Konsili Vatikan II yakin bahwa kebudayaan tiap bangsa justru disempurnakan dengan misteri inkarnasi dan penebusan Kristus (AG. 9). Untuk mewartakan Injil, Gereja perlu melakukan gerak seperti Kristus sendiri dalam penjelmaan, masuk kepada keadaan sosial budaya dan keseharian orang yang dijumpaiNya (AG. 10).

Selain itu, tahun 1970-an inkulturasi turut mewarnai arti misi. Pedro Arrupe (1991) Jenderal Serikat Yesus dalam Kongregasi Jenderal Serikat Yesus ke-32 tahun 1975/1974 menyatakan definisi inkulturasi.

"Inkulturasi adalah pengejawantahan hidup dan amanat Kristiani dalam lingkungan budaya tertentu. Maksudnya pengalaman ini tidak hanya diwujudkan dalam unsur-unsur tertentu yang terdapat dalam budaya yang bersangkutan (ini hanya 
akomodasi dangkal), melainkan menjadi prinsip yang menjiwai, menuntun serta mempersatukan budaya dengan mengubah serta membaharuinya. Jadi, inkulturasi menciptakan sesuatu yang baru". ${ }^{17}$

Dalam inkulturasi tersebut termuat gagasan bahwa dalam perjumpaan dengan budaya lain, Gereja perlu melakukan gerakan inkarnasi masuk ke budaya mereka tetapi juga sekaligus membaharui budaya tersebut lewat penebusan Kristus (AG. 9). ${ }^{18}$

\section{PANORAMA MUSIK LITURGI INDONESIA}

Untuk menjawab pertanyaan pertama, kita perlu ingat bahwa di tanah misi, para misionaris kerap menggunakan seni musik dalam berevangelisasi. Bahkan, para misionaris Yesuit yang masuk di Brazil sejak 1549, dikenal menggunakan media seni musik untuk mengkristenkan penduduk Indian Brazil. Doktrin-doktrin Kristiani diajarkan kepada kaum pribumi dengan menggunakan lagu-lagu Indian dan Portugis (cantigas). ${ }^{19}$ Hal yang mirip terjadi di Manila, para misionaris Yesuit dari Spanyol menggembangkan musik untuk mengekspresikan iman Kristiani. ${ }^{20}$ Di Indonesia, para misionaris ternyata juga melakukan hal serupa. Sejumlah kalangan, baik itu Klerus maupun Awam secara aktif mengupayakan inkulturasi musik liturgi.

Di Jawa inkulturasi musik Gereja dipelopori oleh Hardjasoebrata (1905-1986). Hardjasoebrata dikenal sebagai pencipta lagu dolanan seperti Kupu Kuwe, Mentog-Mentog, Gundul-Gundul Pacul dan Montor-Montor Cilik. Selain menciptakan gending-gending dolanan, klenengan, dan panembrama, Hardjasoebrata juga dikenal menciptakan gending Rerepen Gereja.

Saat bersekolah di Kweekschool Muntilan, ada dorongan kuat pada dirinya untuk beribadah menggunakan bahasa pribumi yang menurutnya lebih orisinal sebab mewakili khasanah budayanya. ${ }^{21}$ Pengalaman ambiguitas tersebut dikarenakan ketidakpuasan Hardjasoebrata menggunakan lagu-lagu terjemahan saat beribadah. Oleh sebab itu dia menggubah lagu dengan laras Jawa yang baginya lebih asli.
"Rasane ora sreg, lagune cara landa koq tembunge basa Jawa. Apa ora bisa yen lagune uga cara Jawa" (rasanya tidak enak, musiknya Belanda tetapi katakatanya dalam bahasa Jawa. Apakah tidak bisa kalau musiknya juga Jawa?)

Hardjasoebrata yang merasakan keterbelahan identitas sebagai orang Jawa (berbudaya Timur) sekaligus orang Katolik (berbudaya Barat) mencari musik yang sreg untuk digunakannya beribadat di Gereja. ${ }^{22}$

Perkaranya, saat itu musik Barat merupakan penanda utama bagi identitas Katolik. Oleh sebab itu saat ide tentang musik Jawa dilontarkan kepada para Katekis pribumi kebanyakan dari mereka tidak setuju. Lagu Jawa dianggap terlalu murahan jika digunakan untuk upacara peribadatan di Gereja. Baru setelah untuk pertama kalinya gamelan Jawa diperkenankan masuk ke dalam Gereja dan diperdengarkan kepada Vicarius Jakarta, Mgr. van Velsel bersama dengan para Imam dan Bruder Belanda pada tanggal 31 Januari 1926, lagu Jawa diterima. Mgr. van Velsel menyatakan bahwa Beliau tidak keberatan jika lagu tersebut dinyanyikan, tetapi bukan untuk Misa. Sebab pada waktu itu, nyanyian untuk Misa memang wajib menggunakan lagu Gregorian dengan syair berbahasa Latin. ${ }^{23}$

Usaha inkulturasi tersebut dilanjutkan oleh Mgr. Soegijapranata S.J. (uskup pribumi pertama di Semarang). Sesudah Perang Dunia II Mgr. Soegijapranata mengumpulkan para tokoh musik tradisional Jawa. Pada tanggal 22 Oktober 1955 Mgr. Soegijapranata membentuk sebuah panitia musik Gereja untuk Keuskupan Semarang yang beranggotakan E. Harjawardaya, Pr., Zoetmulder, S.J., F. Atmadarsana, Hardjasoebrata, Sastropustoko, Y.B. Sukodi, dan Marsudi. ${ }^{24}$ Hasilnya mereka melahirkan tiga buklet yang diterbitkan tahun 1961. Pertama, stensilan "Kidungan Sutji Lagu Djawi" yang berisi lagu ibadat dengan bahasa Latin namun dengan pola lagu pelog untuk menggantikan lagu Gregorian, ditambah tiga lagu dalam bahasa Jawa. Kedua, buklet "Kyriale" yang berisi tiga ordinarium missae bahasa Latin yang dikemas dengan pola lagu pelog. Dan ketiga, buklet yang 
berjudul "Natalia" yang berisi gendhing lagu Natal yang memuat musik dan syair Jawa. ${ }^{25}$

Eksperimen lain dilakukan oleh van Deinse S.J. yang membuat Gamelan Kromantis yang kemudian dinamai Gamelan Supra. Dibuat pada tahun 1957, Gamelan Supra adalah percampuran antara musik Jawa dan Barat. Jika Gamelan Jawa pada umumnya bernada pentatonis, Gamelan Supra muncul bernada diatonis persis seperti instrumen musik Barat. ${ }^{26}$ Dengan kata lain, Gong, Saron, Bonang, Kempul, Kenong, Slenthem dan Gambang tersebut memiliki notasi diatonis kromantis musik Barat. Dengan begitu, Gamelan Supra dapat memainkan berbagai macam genre musik lain seperti Klasik, Jazz bahkan Pop. ${ }^{27}$

Selain itu usaha inkulturasi juga dikerjakan di luar Jawa. Di Manggarai Dere Serani bisa dibilang merupakan proyek transkultural yang berhasil. Dere Serani adalah buku lagu yang berisikan lagu-lagu lokal Manggarai yang dipilih dan dikristenkan seturut selera para komponis pribumi. Di sanalah terdapat kolaborasi antara misionaris dengan musisi pribumi. ${ }^{28}$

Di Pulau Timor, pada tahun 1957, P. Vincent Lechovic, S.V.D. berupaya menggunakan lagu-lagu dari kebudayaan Dawam dengan menerbitkan buku nyanyian liturgi dalam bahasa Timor yang berjudul "Tsi Tanaeb Uis Neno". Hal ini untuk memperkaya lagu inkulturasi yang sudah ada yakni Jubilate.

Sebelumnya, mayoritas umat Katolik di Flores dan Timor dalam peribadatan memang telah fasih menggunakan buku lagu Jubilate. ${ }^{29}$ Buku nyanyian Jubilate dibuat oleh Pastor Does S.V.D. (Pustardos) pada tahun tahun 1930. Lagu-lagu di dalam buku nyanyian Jubilate berisi tentang lagu-lagu romantis abad XIX dan dilengkapi dengan beberapa lagu Gregorian yang sudah sering dipakai selama bertahun-tahun. Pada tahun 1947, buku Jubilate tersebut kemudian disempurnakan kemudian dijadikan buku pegangan bagi umat Katolik di Indonesia Timur dan beberapa tempat lain.

\section{KIPRAH PRIER}

Prier hanyalah salah satu dari sekian banyak tokoh-tokoh yang mengusahakan inkulturasi musik liturgi. Untuk melihat konteks karya misi Prier, kiranya baik jika kita membingkai (framing) kiprah Prier dalam peta kerangka misiologi. Paul G. Hiebert menunjukkan ada tiga era sejarah dalam misi kekristenan.

Pertama, disebut era kolonial yang ditandai dengan masa penjelajahan dan perdagangan. Saat perjumpaan bangsa Eropa dengan etnis lain. Respon yang kerapkali muncul adalah arogansi superioritas personal atas ras dan budaya Barat. Perkembangan teknologi dan ilmu pengetahuan membuat orang Barat lebih percaya diri saat berhadapan dengan non-Barat yang primitif. Rasa superior ini menyebabkan bangsa Barat menjajah bangsa lain. Sebagai orang kulit putih mereka merasa bertanggung-jawab untuk mendidik orang kulit berwarna agar lebih berbudaya. Para misionaris juga terpengaruh oleh semangat zaman ini. ${ }^{30}$ Para misionaris merasa bertanggung-jawab untuk mengenalkan kekristenan dan menyelamatkan bangsa kafir. Oleh karena itu mereka menyebarkan ajaran tentang dosa, pengampunan, dan keselamatan abadi dalam teologinya. Mereka juga memperkenalkan pengobatan medis, pendidikan akademik, cara berdoa, style berbusana seturut model Barat yang dianggap lebih maju. ${ }^{31} \mathrm{Hal}$ ini didasari dengan epistemologi yang berkembang saat itu yakni positivisme. Di sinilah, dasar dari adanya suatu kepercayaan universal. Pengetahuan saintifik dianggapnya akurat dalam memotret seluruh realita yang ada. Pengagungan terhadap cara berpikir positivistik ini mempengaruhi cara berpikir Barat. Dampak positifnya, sarana prasarana rumah sakit, pendidikan dan pertanian modern dibuat oleh para misionaris untuk memperadabkan kehidupan setiap orang di tanah koloni.

Kedua adalah era anti-kolonial. Pada era ini, penjajahan dan arogansi Barat menjadi gunjingan baik di daerah koloni maupun di Eropa sendiri. Hal ini turut mempengaruhi perspektif misi yang berdampak pada upaya pembangunan Gereja lokal/pribumi. Kebangkitan gereja-gereja lokal ditandai deng- 
an prinsip kemandirian lewat 3 hal: selfsupporting, self-governing, dan self-propagating. Di sinilah kontekstualisasi teologi semakin berkembang. Perjumpaan para misionaris dengan umat pribumi mengubah pendekatan dari konfrontasi ke arah dialog. Positivisme runtuh sejalan dengan perkembangan anti-kolonialisme. Tak bisa lagi ngotot menunjukan bahwa pengetahuan Barat paling unggul objektif dan universal, orang hanya bisa mengatakan bahwa pengetahuan Barat dapat digunakan untuk memecahkan permasalahan hidup saat ini. Paradigma cara berpikirnya lebih pragmatis daripada pencarian akan yang ontologis. Pengetahuan menjadi lebih subjektif, tak lagi ada pengetahuan universal. ${ }^{32}$ Di momen inilah antikolonialisme turut mempertanyakan identitas kekristenan universal dan mendorong munculnya identitas kekristenan partikular.

Ketiga adalah era global. Saat anti-kolonialisme tidak meletakkan dasar yang solid. Ada dua reaksi terhadap anti-kolonialisme. Pertama, muak dengan relativisme dan kembali mencari kepastian dalam bentuk yang lebih subtil atas neokolonialisme. Kedua, lebih melihat ke depan. Respon yang kedua ini hendak bermaksud melampaui pengalaman pluralisme guna menemukan dasar yang lebih dalam. Semisal, jika pendukung kolonialisme melihat misi adalah sarana pemberadaban yang positif sedangkan anti kolonial melihat buruknya upaya penghancuran budaya lokal oleh misi, titik tengah dua oposisi itu perlu diupayakan. ${ }^{33}$ Pendukung kolonial mungkin berpendapat bahwa seseorang untuk menjadi Kristen terlebih dahulu harus menjadi Barat. Sedangkan anti-kolonial berpendapat bahwa seseorang harus mempertahankan budayanya. Maka, kontekstualisasi kritis yang muncul adalah kesadaran baru bahwa Kitab Suci itu melampaui budaya. Maksudnya, Allah itu ada untuk semua makhluk dalam keberagaman bangsa dan budaya di dunia. Allah bukan hanya milik budaya Barat.

Dari ketiga era tersebut, kita bisa menilai sendiri locus misi Prier, S.J. Sewaktu kecil di Jerman, Prier dibesarkan dalam suasana chauvinistik Perang Dunia II di mana saat itu Adolf Hitler sebagai Führer (pemimpin) partai Nazi (Nationalsozialist) Jerman. Setelah menjadi Yesuit, Prier, S.J. datang sebagai misionaris ke Indonesia pada pasca kemerdekaan Indonesia yakni tahun 1964 Pertama kali datang ke Indonesia Prier merasakan bukan hanya gerahnya iklim di Indonesia tetapi juga suasana politik Indonesia. Pasalnya, setelah kemerdekaannya negara muda ini mengalami pergolakan huru-hara kekuatan politik antara militer, nasionalis, partai-partai Islam dan komunis. Mereka saling bersaing memaksakan pandangan mereka untuk negara baru ini. ${ }^{34} \mathrm{Di}$ dalam tubuh Gereja sendiri, saat itu sedang terjadi ketegangan suasana indonesianisasi atau pribumisasi. Suasana indonesianisasi digambarkan F.X. Danuwinata S.J. sebagai berikut

Th. Koendjono S.J. menunjukkan bahwa penyebaran agama Katolik di Indonesia juga dibarengi dengan masuknya kebudayaan Barat oleh misionaris-misionaris Barat. Dengan begitu perkembangan Gereja Katolik berbareng-an dengan penanaman kolonialisme. Kolonialisme tersebut menimbulkan sikap superioritas dari Barat, dan inferioritas dari Timur yang dijajah. Inferioritas itu mengakibatkan pemujaan kebudayaan Barat sekaligus meragukan nilai-nilai pribumi. Dalam praktiknya, nilai-nilai Barat dalam Gereja Katolik biasanya menang diunggulkan, sebab budaya Barat berkelindan dengan Kekristenan, dan selera Barat menjadi selera bangsa yang berkuasa. Oleh karena itu, hidup menggereja sangat kental dengan budaya Barat. Ketika ide modernisasi muncul dari Barat. Ide tersebut memunculkan gerakan Konsili Vatikan II di dalam tubuh Gereja. Di Indonesia hal ini mengakibatkan indonesianisasi Gereja Katolik yang berarti membuat sesuatu bersifat Indonesia. Nilai-nilai dari kebudayaan Indonesia yang dikagumi orang Barat yang sudah bosan dengan kebudayaan Barat hendak ditampilkan di Indonesia. Dengan begitu, lagi-lagi tampak bahwa hegemoni Barat cukup kuat di dalam tubuh Gereja Katolik. Idealnya indonesianisasi memang dilakukan oleh orang Indonesia, supaya Indonesianisasi Gereja Katolik tidak menjadi occidentalisasi lagi. ${ }^{35}$

Untuk memahami perdebatan tentang indonesianisasi seperti dikatakan Koendjono 
S.J, kita harus paham terlebih dahulu adanya respon Gereja Indonesia terhadap kebijakan Presiden Soekarno yang antiBarat dan muaknya kaum pribumi terhadap hegemoni Barat. Hal ini tampak dalam bantuan finansial dari Eropa yang digelontorkan untuk misi di Indonesia. Pemerintah Indonesia sebenarnya juga mendapat bantuan dari Misi untuk menopang pembangunan. Seperti di tahun 1958, para Uskup Jerman membentuk organisasi Misereor untuk membantu para misionaris dalam menjalankan pembangunan. Untuk tujuan yang sama, tahun 1961 perkumpulan Katolik Belanda membuat lembaga Vastenactie. PBB dan pemerintah Jerman juga membuat program serupa untuk membantu Gereja Katolik dan Protestan. Selebihnya ada banyak sekali program bantuan dari Eropa untuk Indonesia. Tetapi karena situasi politik, Soekarno saat itu meneriakkan "Go to hell with your aid!". Hanya setelah Soeharto menjadi presiden maka bantuan dari Barat datang kembali ke Indonesia. ${ }^{36}$

Perspektif yang muncul saat itu, berbagai bantuan Barat kepada Indonesia menunjukkan adanya pembagian kekuasaan dari Ibu Gereja di Eropa kepada gereja-gereja muda di Indonesia. Selain itu adanya rasa inferioritas dari kaum muslim sebagai agama mayoritas tetapi minder saat dihadapkan dengan Kristen yang minoritas tetapi berkuasa memegang institusi pendidikan, media massa, dan rumah sakit. Dengan begitu lembaga Gereja kerap dipandang sebagai instrumen dominasi kekuasaan Barat. ${ }^{37}$

Problem identitas Gereja Katolik seperti di atas kemudian ditanggapi dengan strategi usaha agar Gereja Katolik menjadi semakin Timur melepaskan diri dari stigmatisasi agama Barat. Gereja mulai memikirkan untuk melaksanakan indonesianisasi. Sidang MAWI 13-23 November secara khusus membahas tentang pemribumian atau pembangunan Gereja setempat di Indonesia. Dengan terang Konsili Vatikan II (AG. 1922) Indonesianisasi diusahakan agar Gereja dan kebudayaan Indonesia dapat bersatu. Untuk itu, indonesianisasi berarti membuka pintu untuk berkomunikasi saling memberi dan menerima (LG.13). Singkatnya, indone- sianisasi adalah upaya pengintegrasian Gereja di Indonesia. Bukan semata demi nasionalisme tetapi juga katolisisme. ${ }^{38}$

Oleh karena itu gagasan indonesianisasi diupayakan dengan memperhatikan ciri khas Indonesia yakni Pancasila, Bhinneka Tunggal Ika, Garis-Garis Besar Haluan Negara (GBHN) dan Undang-Undang Dasar (UUD 1945). Gereja secara sadar melihat bahwa pemerintah ingin meningkatkan pemeliharaan kebudayaan nasional untuk diarahkan kepada penguatan kepribadian Bangsa. Atas dasar itu, masing-masing keuskupan tidak ingin menyamaratakan iman umat tetapi menghormati kekayaan perbedaan tiap-tiap daerah. Diharapkan dengan indonesianisasi Gereja dilihat secara positif sebagai bagian dalam proyek pembangunan Indonesia, bukan benda asing (corpus alienum). MAWI berharap agar umat katolik yang merupakan minoritas bisa menjadi sakramen keselamatan yang bermutu.

Langkah konkretnya, indonesianisasi dapat dikatakan baik jika tenaga, karya dan pimpinan tarekat dari pribumi. Oleh karena itu MAWI mendorong agar para uskup juga pimpinan tarekat dipegang dari kalangan pribumi. ${ }^{39}$ Usaha pergantian antara misionaris dan pribumi ini ternyata menimbulkan ketegangan. Sebagai misionaris Barat, Prier mengalami ketidaknyamanan. Sewaktu tinggal di Kolsani dia melihat adanya perpecahan antara kubu Yesuit pribumi dan asing. Pertengkaran itu membuat beberapa misionaris memilih untuk pulang ke negara asalnya.

Untuk itu, saat Konsili Vatikan II menghasilkan pandangan-pandangan baru di dalam tubuh Gereja Katolik universal. Prier diajak beberapa frater Kolsani mengadakan Dies Liturgicus pada tanggal 18 Desember 1965. Acara Dies Liturgicus yang diadakan di Kolsani tersebut berbentuk seminar, pameran, dan perayaan liturgi dalam ritus baru seturut Konsili Vatikan II. Pada waktu itu, Prier diajak oleh Fr. Artur Weibel, S.J. untuk membuat lagu baru yakni proprium dan ordinarium. Pada awalnya Prier, S.J. menolak karena belum pernah mengarang sebuah lagu. Tetapi, akhirnya Prier, S.J. berhasil mengarang lagu mazmur 
seperti "Bangkitkanlah" (MB. 319) dan "Misa Raya II" (MB. 177 dst.) dalam bahasa Indonesia. Dengan demikian, dalam Dies Liturgicus tersebut, untuk pertama kalinya di Gereja Kotabaru perayaan ekaristi dirayakan menggunakan bahasa Indonesia.

Di Kolsani, Prier banyak mendapat pelajaran berharga tentang inkulturasi. Di Kolsani pula Prier bertemu Paul Widyawan, seorang guru musik di Akademi Kateketik Indonesia (AKI) sekaligus seorang pendiri dan pemimpin kelompok Paduan Suara Vocalista Sonora. ${ }^{40}$ Paul Widyawan mengungkapkan bahwa proses pembaharuan musik liturgi di Indonesia hendaknya dilakukan dengan menciptakan lagu liturgi baru yang bernuansa Indonesia, jadi bukan hanya menerjemahkan lagu-lagu dari Barat ke dalam bahasa Indonesia. Paul Widyawan selalu berkata, "musik Gereja di Indonesia hanya akan maju sebagai musik yang khas Indonesia." 41 Begitulah gagasan Paul Widyawan yang adalah seorang pribumi ternyata cukup mempengaruhi pikiran Prier yang adalah seorang misionaris dari Barat. Gagasan tersebut kemudian dibicarakan kepada Pater Soenarja S.J. sebagai Provinsial yang berujung kepada penugasan Prier untuk membuat karya baru di bidang musik.

Prier semakin intens berdiskusi dengan Paul Widyawan. Pertemanannya dengan Hardjosoebroto, Siswanto dan Sukodi semakin memperkaya pengetahuannya tentang musik Jawa. Selain itu para dosen yang berhaluan Konsili Vatikan II seperti Tom Jacobs S.J., Hardawiryana S.J. dan Stolk S.J. memberi semangat untuk menggarap inkulturasi musik di Indonesia. Secara khusus Stolk sebagai Rektor Kolsani sekaligus dosen liturgi mendorong Prier untuk membuat inkulturasi liturgi yang khas Indonesia.

Setelah diskusi dengan berbagai pihak akhirnya disepakati untuk merintis Pusat Musik Liturgi (PML). PML didirikan dengan ide untuk menangani musik Gereja dan menciptakan lagu-lagu liturgi baru yang khas Indonesia. PML diharapkan bisa mempengaruhi gereja Katolik di Indonesia untuk mengembangkan musik Liturgi khas Indonesia.
Pada tahun 1973 dalam Kongres Liturgi II PWI Liturgi untuk Musik Gereja, muncul keputusan untuk membuat buku lagu dan doa yang dapat mempersatukan identitas Gereja Katolik Indonesia. MAWI yang saat itu getol dengan Indonesianisasi mendukung rencana tersebut dan mengutus PML untuk mengerjakan proyek tersebut. Dalam proses pembuatan buku lagu dan doa tersebut Prier tampaknya sadar bahwa problematik integrasi nasional sedang terjadi di daerah-daerah di Indonesia. Pemerintah Indonesia saat itu sedang membangun identitas kebudayaan Nasional. Suku-suku Jawa, Dayak, Batak, dan lainnya dihimpun menemukan identitas baru sebagai orang Indonesia yang berbudaya Indonesia.

Problematik integrasi nasional ini memunculkan persoalan baru seperti suku Tionghoa yang tidak berasal dari daerah di Indonesia. Oleh sebab itu, Gereja yang saat itu dianggap asing karena berasal dari Barat juga mendapat imbasnya. Para misionaris dipersulit kehadirannya di Indonesia. Departemen Agama mempunyai peraturan quotum terhadap misionaris dari asing. Mempertimbangkan situasi postkolonial tersebut, Prier melanjutkan mandat dari MAWI membuat buku lagu dan doa yang bercerminkan budaya Indonesia. Setelah melakukan pelbagai macam lokakarya dan terinspirasi buku Gotteslob di Jerman, akhirnya lahirlah buku Madah Bakti (1980).

Pada saat launching, Mgr. Anicetus B. Sinaga, OFM.Cap. Sebagai ketua PWI Liturgi menekankan perlunya inkulturasi untuk memadukan perjumpaan iman dan budaya. ${ }^{42}$ Madah Bakti sebagai tonggak sejarah musik Gereja Indonesia memuat perpaduan (hybrid) lagu-lagu dari Barat dan etnik Indonesia. Ada beberapa tanggapan terhadap buku Madah Bakti. Tanggapan positif yang muncul adalah pujian atas banyaknya lagu inkulturasi yang khas Indonesia di dalam Madah Bakti. Selain itu, harga Madah Bakti cukup terjangkau bagi umat kebanyakan. Adapun resistensi dan tanggapan negatif yang muncul melihat porsi lagu Gregorian sangat minim. Selain itu terkesan Madah Bakti sangat yogyasentris. Mgr. Sinaga menanggapinya dengan me- 
nunjukkan perhitungan bahwa perbandingan lagu Jawa dan lagu Flores ternyata lebih banyak lagu Flores di dalam Madah Bakti. ${ }^{43}$ Lepas dari itu semua, banyak orang melihat Madah Bakti adalah buku pemersatu umat Katolik di Indonesia.

Madah Bakti memang tidak dimaksudkan sebagai buku wajib untuk nyanyian misa. Oleh karena itu penyebaran Madah Bakti tidak di seluruh Indonesia. Dalam hal ini tiap-tiap keuskupan memiliki kebijakannya masing-masing. Prier mencatat bahwa Regio Flores tidak serta merta menggunakan lagu Madah Bakti karena sudah ada buku Syukur kepada Bapa. Setidaknya dalam 6 tahun tercatat Madah Bakti terjual kurang lebih satu juta buku. ${ }^{44}$

Tidak berhenti pada karya monumental Madah Bakti, sebagai instansi yang didirikan untuk menggali dan mengangkat tradisi musik sesuai amanat Konsili Vatikan II, PML terus berproses kreatif. Sejak dari edisi perdana tahun 1980, Madah Bakti terus menerus diperbaharui untuk menunjukkan bahwa inkulturasi itu on going process. PML juga berusaha mengembangkan khazanah musik tradisional di Indonesia agar umat dapat merayakan liturgi sesuai dengan sifat perangai dan jiwa kebudayaan setempat. Tujuannya, agar umat dapat lebih memahami, menjiwai, merasakan liturgi sehingga terlibat aktif dalam perayaan liturgi. ${ }^{45}$ Dalam rangka penyebaran wacana inkulturasi tersebut, PML memiliki beberapa program yakni studi, kreasi, produksi dan edukasi.

\section{YANG UNIVERSAL BERTEMU YANG LOKAL}

Untuk menjawab pertanyaan ketiga, setelah melihat 'bentuk' kiprah Prier dalam mengupayakan inkulturasi musik liturgi di Indonesia, penulis selanjutnya ingin merefleksikan 'isi' inkulturasi Prier. Sebagai framing, Richard Friedli melihat pembabakan perkembangan misiologi ${ }^{46}$ sebagai berikut: (1) Kolonialisme yang diboncengi para misionaris menumbuhkan gereja-gereja lokal di luar Eropa. Banyak teolog dari Asia, Afrika, dan Amerika Latin melihat teologi Eropa sebagai teologi universal. Dampaknya, beberapa gereja-gereja lokal mencoba membangun teologi inkulturasinya sendiri. Dengan begitu dialog dengan yang lokal dirasa penting. (2) Sekularisasi, globalisasi dan multikulturalisme cukup mempengaruhi perkembangan teologi inkulturasi. Penyebabnya adalah faktor migrasi yang diakibatkan oleh kolonialisme membuat para teolog tersentak melihat fenomena multikulturalisme dan pluralisme agama di negara-negara Eropa. (3) Konsili Vatikan II mencoba memahami keberadaan Gereja dalam relasinya dengan budaya dan agamaagama lain. ${ }^{47}$ Karl Rahner kemudian mengajak agar Gereja sadar dengan konteks keberadaan Gereja di dunia tersebut. ${ }^{48}$ Untuk itu gereja-gereja lokal ditantang untuk lebih mandiri dan dewasa. Tentunya dengan tetap sepaham dengan Gereja universal (sentire cum ecclesiae).

Beranjak dari pembabakan yang diutarakan Friedli tersebut, kita bisa menangkap adanya interaksi dialektikal antara iman Kristiani dengan budaya-budaya lain. Inkulturasi yang merupakan interaksi resiprokal iman Kristiani dengan budaya-budaya lain itu menuntut masuknya Injil ke dalam budaya setempat kemudian mentransformasikan ke dalam Kerajaan Allah. ${ }^{49}$

Sebagai man of the church keterlibatan Prier dalam mengupayakan inkulturasi kiranya tidak muncul begitu saja. Penulis menginterpretasikan inkulturasi Prier dilatarbelakangi oleh beberapa faktor yakni (1) tradisi inkulturasi para misionaris Yesuit, (2) Konsili Vatikan II dan (3) situasi Gereja saat itu yang bergejolak menghadapi komunisme, anti Barat dan Indonesianisasi.

Pertama, Prier adalah seorang Yesuit. Dalam sejarah misi, sebelum istilah itu dikeluarkan oleh Konsili Vatikan II, tokoh-tokoh Yesuit seperti Matteo Ricci, Nobili, de Britto sudah lebih dahulu melakukan inkulturasi di tanah misi. Dalam perjumpaannya dengan dengan 'the other' para misionaris Yesuit dikenal memiliki kemampuan untuk bersentuhan dengan kebudayaan yang berbeda sehingga menghasilkan kebudayaan baru yang hibrid. ${ }^{50}$ Mereka memiliki misi apostolis yakni membantu jiwa-jiwa (help of souls) 
dan demi kemuliaan Allah yang lebih besar (ad maiorem Dei gloriam). ${ }^{51}$ Terkait dengan misi ke benua lain, P.J. Nadal mengungkapkan bahwa para Yesuit berkehendak menjadikan seluruh bumi ini sebagai rumah mereka (totus mundus nostra fit habitatio). Tak mengherankan, dengan begitu kristenisasi dan modernisasi cara berpikir Barat disebarkan oleh mereka ke daerah koloni, terlebih lewat jalur pendidikan humaniora. ${ }^{52}$

Kedua, dengan semangat aggiornamento (pembaharuan) Paus Yohanes XXIII membuka Konsili Vatikan II. Semangat tersebut melahirkan konsepsi tentang pemahaman diri Gereja (ecclesia ad intra) dan dorongan untuk masuk ke dunia (ecclesia ad extra) yakni berdialog dengan agama dan budaya yang berbeda. ${ }^{53}$ Cara memandang diri Gereja tersebut menentukan cara berada Gereja di tengah masyarakat. Implikasinya, dengan semangat aggiornamento cara berliturgi diubah yakni dengan menggunakan bahasa-bahasa lokal, imam menghadap ke umat dan musik liturgi bernuansa inkulturatif.

Ketiga, saat Prier datang ke Indonesia aktivitas para misionaris memang dibatasi ${ }^{54}$ lewat peraturan quotum. ${ }^{55}$ Situasi tersebut semakin dipersulit akibat konflik Indonesia dengan Belanda perihal Nieuw Guinea atau Irian Jaya (IRIAN: Ikutan Republik Indonesia Anti Nederland). Hal tersebut berakibat hampir tidak ada misionaris Belanda yang diijinkan masuk ke Indonesia, ${ }^{56}$ padahal imam pribumi Indonesia masih sangat sedikit. ${ }^{57}$

Kecemasan lain yang muncul adalah ancaman komunisme. Sebenarnya, para tokoh PKI telah menerima Pancasila dan mengecam partai Masyumi Muslim yang berkhianat dengan Pancasila lewat Darul Islam. Selama Pancasila diterima menjadi landasan nasional, kebebasan beragama akan terjaga dan Katolik tidak perlu takut. Tetapi bagaimanapun kelestarian Gereja Katolik akan terancam jika golongan Islam maupun Komunis terlampau kuat. Mengenai ancaman tersebut Mgr. Soegijapranata berpendapat. ${ }^{58}$
"Kalau Darul Islam menang, mereka menggantung kita di puncak menara; kalau PKI yang menang, tengkuk leher kita ditembak di sakristi."

Untunglah kejadian dramatis terjadi saat para uskup Indonesia mengikuti Konsili Vatikan II. Sesudah tinggal di Roma hingga bulan Desember para uskup Indonesia baru mengetahui ada kudeta 30 September 1965. Bahaya "tengkuk leher ditembak di sakristi" sudah lewat karena golongan Komunis disingkirkan dari masa depan Indonesia, dan ancaman "digantung di puncak menara gereja" oleh pihak muslim ekstrim juga dicegah dengan dibentuknya Orde Baru oleh Soeharto. ${ }^{59}$

Untuk itu sebagai man of the church Prier getol di dalam mengerjakan proyek inkulturasi. Tetapi tantangannya, selalu ada tegangan-tegangan kebudayaan yang menimbulkan dinamika berinkulturasi seperti tegangan budaya Universal-Lokal, BaratTimur, dan Modern-Tradisional.

Berbicara tentang tegangan antara yang lokal dengan universal ada beberapa perkara yang dihadapi oleh Prier. Pertama, masih ada orang yang menginginkan agar Gereja lebih eksklusif dan seragam. Alasannya, Gereja Katolik yang selama berabad-abad menekankan segi universal dan uniformitas seakan meninggalkan cita-cita tersebut dengan mengijinkan keberagaman bahasa dan unsur budaya masuk ke dalam lingkungan Gereja. Dalam hal ini Prier menunjukkan bahwa Konsili Vatikan II membuka pintu agar liturgi disesuaikan dengan budaya setempat. "Gereja tidak menganggap satu corak kesenian pun sebagai khas bagi dirinya" (SC. 123). Oleh sebab itu perayaan liturgi harus sesuai dengan jiwa dan kebudayaan yang berbeda-beda (SC. 37-40). Memang keanekaragaman liturgi bisa memperkaya tetapi juga menimbulkan ketegangan dan perpecahan. Untuk itu perbedaan itu jangan sampai merugikan kesatuan Gereja, tetapi tetap berpegang pada iman bersama (KGK. 1206). ${ }^{60}$

Kedua, perdebatan tentang lokal dan universal kerapkali bergeser kepada kecenderungan pandangan relativisme dengan 
absolutisme. Kekristenan yang dibawa dari Barat ke daerah lain mengakibatkan identifikasi budaya Barat sebagai budaya Kristen. Oleh sebab itu kerap terjadi pangagungagungan budaya Barat begitu juga sebaliknya merelativir budaya Gereja. Tetapi lebih dari itu, secara umum dampak dari Globalisasi adalah situasi homogenisasi budaya. Saat Prier melakukan lokakarya ke daerah-daerah, Prier banyak menemui fenomena budaya pop. Perkembangan teknologi musik menguasai kebudayaan setempat. Dengan begitu, ada pertarungan antara budaya modern dan tradisional. Banyak generasi muda tidak memahami lagi musik daerahnya. Atau bisa juga dikatakan bahwa secara umum kebudayaan lokal sebenarnya sudah bercampur dengan yang global.

Maka, tak ada batas perbedaan yang jelas antara kebudayaan primitif lokal yang satu dengan yang lainnya. ${ }^{61}$ Sebab, komunikasi global menjadikan budaya-budaya pribumi terhomogenisasi budaya global universal. ${ }^{62}$ Hasil dari homogenisasi budaya adalah dominasi imperialisasi satu budaya terhadap budaya lainnya. Dalam pengalaman lokakarya PML dan Prier, hal ini tampak dalam difusi musik pop modern Barat yang merembes di budaya etnik lokal Indonesia. Hal ini menyebabkan banyak regenerasi musik lokal macet sebab budaya mereka telah terhibridisasi. ${ }^{63}$

Dinamika relasi antara Gereja dan budaya-budaya Indonesia tersebut merupakan proses yang terus menerus diupayakan. Di bawah ini, penulis akan memberikan interpretasi terhadap 'isi' inkulturasi yang dilakukan Prier, S.J. dalam dinamika tegangan perjumpaan iman dan budaya.

Pertama, inkulturasi menjadi gambaran 'yang universal masuk ke yang lokal'. Oleh sebab itu Prier sebagai misionaris tampil sebagai pihak yang berjumpa dan bekerjasama dengan yang lokal seperti Paul Widyawan, tim PML, peserta lokakarya, denominasi Gereja Protestan dan agama lainnya untuk bersama-sama membuat proyek musik inkulturasi. Dalam hal ini Prier tampil luwes dengan melihat kaidah inkulturasi sebagai guidelines daripada policy. Selain itu seperti lazimnya para misionaris yang tidak lebih mendukung kolonial Barat daripada pribumi, Prier bisa dikategorikan juga sebagai manusia in between. Dalam ketegangan oposisi biner antara BaratTimur, Prier tampil sebagai misionaris yang berada di posisi tengah antara kedua kubu kebudayaan tersebut. Menjadi manusia in between membuat Prier mampu menegosiasikan tradisi kultural di Jerman dan Indonesia sehingga menghasilkan proses kreatif yang baru. Contohnya, buku Gotteslob yang diadaptasi menjadi buku Madah Bakti. Atau buku bermain piano karya Johnson yang diadaptasi menjadi buku Menjadi Organis. Perjumpaannya dengan Paul Widyawan, Hardjasoebrata, Siswanto, Dulkaeni juga mendorong dia untuk mesistematisasikan musik Timur dalam ranah notasi musik Barat. Hal ini menghasilkan ambiguitas dirinya sebagai orang Barat tetapi ingin seperti Timur.

Kedua, inkulturasi Prier diumpamakan seperti upaya Pieris untuk membaptis Gereja ke Sungai Yordan Asia. Belajar dari Huvang M.S.F. dan Paul Widyawan, metode inkulturasi Prier menjadi cukup khas. Lewat metode lokakarya, inkulturasi Prier bukan sekadar mengambil budaya Timur kemudian dimasukkan dalam musik Gereja. Bukan pula sekadar menerjemahkan Lagu Barat dengan bahasa Indonesia, tetapi dia mencari gaya Indonesia, atau menurut bahasa Pieris mencari rasa Asia dalam musik liturgi inkulturasi. ${ }^{64}$ Tak ada usaha lain, Gereja di Indonesia berusaha dibaptisnya di dalam sungai Yordan suku-suku lokal di Indonesia. Oleh sebab itu, Prier rela pergi keluar masuk pedalaman Indonesia untuk menemukan cita rasa musik suku-suku di Indonesia. Dengan dibaptis dalam tradisi Indonesia, Gereja diajak untuk duduk bersila di hadapan guru tradisi lokal di Indonesia sebagai Gereja yang belajar (ecclesia discens) bukan sebagai Gereja yang mengajar (ecclesia docens). ${ }^{65}$ Sebagai orangnya Gereja, Prier berusaha masuk dalam suasana ini. Lewat lokakarya dengan prinsip rendah hati, kenosis dan mau belajar kebudayaan setempat, dia membantu umat untuk menciptakan musik liturgi inkulturasi. 
Ketiga, Lokakarya merupakan metode eksperimentasi yang khas dilakukan oleh Prier. Tujuan dari lokakarya adalah untuk menangkap cita rasa kebudayaan setempat. Dengan begitu lagu inkulturasi dapat memunculkan "sreg" (manunggaling tembang lan tembung) sesuai dengan sitz im leben dan rasa lokal.

Lewat PML, Prier membuat musik hibrid Gereja universal tetapi dengan rasa lokal. Untuk itu mau tidak mau harus dia "terjun ke bawah" sebab musik etnik hanya dapat ditemukan di daerah-daerah. ${ }^{66}$ Umat beriman pada akar rumput pun berperan sebagai inkulturator dengan menunjukkan sensus fidelium (cita rasa umat beriman). Dinamika benturan-benturan kebudayaan tersebut dilibati oleh Prier kemudian menghasilkan ciptaan baru yang bernuansa lokal sekaligus gerejawi.

Metode lokakarya yang dilakukan PML memiliki dua model. Pertama, lokakarya dengan cara memanggil para musisi dari daerah untuk berkumpul di Yogyakarta. Kedua, Prier bersama tim PML berkunjung ke daerah-daerah untuk mengerjakan mengerjakan komposisi musik bersama. Lokakarya model pertama, dilakukan saat PML mendapat tugas membuat buku doa dan lagu Madah Bakti (1980). Lokakarya model yang kedua dilakukan setelah Madah Bakti terbit, tim PML terjun ke daerah-daerah Nusantara. Sebab PML berkeyakinan bahwa musik inkulturasi seharusnya berkembang dari akar rumput (grass root). ${ }^{67}$

Keempat, Madah Bakti merupakan usaha pengakaran iman kristiani ke dalam bangsa Indonesia. Untuk itu buku lagu Madah Bakti disesuaikan dengan gambaran Kebudayaan Nasional yang dibangun Pemerintah Indonesia. Jika Soekarno sangat membatasi lagu-lagu Barat dan mencekal musisi Indonesia seperti Koes Plus yang identik dengan Everly Brothers. Orde Baru membuka pasar musik Barat masuk ke Indonesia. Dengan begitu Grup Rock semacam Rolling Stones dan Depp Purple dapat ditiru oleh Gito Rollies, God Bless, Slank dan lainnya. Meski demikian Orde Baru tetap membatasi jenis musik. Harmoko sebagai menteri penerangan melarang lagu- lagu cengeng (soppy song) yang dianggapnya berselera rendahan dan melemahkan semangat hidup. ${ }^{68}$

Dalam kesadaran bahwa lagu lokal Indonesia bersaing dengan lagu asing, jika Orde Lama memilih menolak lagu asing, Orde Baru memilih jalan negosiasi. Berbeda dengan Soekarno yang anti-Barat, Ki Hadjar Dewantara dan RM Soerjo Putro memilih menegosiasikan budaya Barat. Harapannya agar musik tradisional Indonesia dapat dipahami, dimainkan dan dilestarikan. Hal ini dilakukan karena teori musik Eropa sangat mendominasi musik Indonesia. ${ }^{69}$

Sebagai minoritas, posisi Gereja yang tercermin lewat MAWI tampak mendukung pemerintah Orde Baru. Turut serta dalam euforia tumbangnya komunisme, secara terang-terangan Gereja Katolik mendukung penuh politik kebudayaan Orde Baru saat itu. Oleh sebab itu musik inkulturatif yang terkumpul dalam Madah Bakti yang dikerjakan Prier bersama tim PML dibangun pula oleh politik kebudayaan Orde Baru. Strategi politik kebudayaan Orde Baru yang ditangkap Prier saat itu adalah kebudayaan nasional merupakan puncak-puncak kebudayaan di daerah-daerah yang dikenal oleh masyarakat melalui Undang-Undang Dasar 1945 pasal 32. Istilah puncak-puncak kebudayaan itu bersumber dari konsep Ki Hajar Dewantara tentang kebudayaan nasional yang muncul sejak zaman pra kemerdekaan. ${ }^{70}$

Kelima, jika Ary Roest Crollius menggambarkan tahapan inkulturasi yakni translasi, adaptasi, dan transformasi. Penu-lis berpendapat bahwa proses inkulturasi Prier sudah mencapai tahap transformasi di mana Gereja muda memainkan peranan lebih aktif bukan hanya berasimilasi melainkan juga dalam transformasi kebudayaan. Transformasi kultural yang dihasilkan oleh proses inkulturasi Prier tampak dalam penghargaan terhadap budaya lokal dan upaya inkulturasi yang dilakukan tanpa henti (on going process). Tidak hanya lokakarya yang terus menerus dilakukan hingga saat ini, tetapi di tempat lokakarya diadakan upaya pengintegrasian ekspresi iman Gereja juga terus dilakukan. Banyak seniman lokal merasakan 
bahwa alat musik tradisional mereka dihargai Gereja dan bernilai religius. Dengan begitu sebagai upaya pengintegrasian $100 \%$ katolik $100 \%$ Indonesia, inkulturasi yang dilakukan Prier bukan hanya merupakan proses asimilasi melainkan juga mentransformasikan kebudayaan lokal. Dengan kata lain inkulturasi Prier S.J. bisa kita sebut sebagai transformasi mendalam nilai-nilai budaya asli yang diintegrasikan ke dalam lagu liturgi Gereja. Lagu-lagu inkulturasi Madah Bakti berusaha mengungkapkan ekspresi iman seturut situasi di Indonesia, yang dalam hal ini lebih mengandalkan sensibilitas (rasa) daripada lagu Barat. ${ }^{71}$

Dari interpretasi ini, penulis menarik kesimpulan bahwa sebagai man of the church inkulturasi yang dilakukan Prier bernuansa inter-kultural. Maksudnya, pengakaran injil ke budaya partikular tidak dilakukan dengan menggurui tetapi dengan sikap dialog terbuka, dan hubungan resiprokal saling belajar seperti yang sudah dilakukan oleh Prier. ${ }^{72}$ Meminjam pemikiran ruang ketiga dari Bhabha, di mana inter berarti ruang antara (between from one to the other). Interkultural teologi berarti pemahaman teologis 'antara' berbagai kebudayaan dan iman yang berbeda. Asumsinya, teologi interkultural hendak membuat proses inkarnasi dalam budaya lokal di mana pribumi dapat merasakan at home di dalam Gerejanya (particular church). Dengan demikian, umat dapat merasakan keberadaan Gereja partikular (LG. 123) sekaligus menemukan kebenaran dalam kesatuan Gereja universal yang katolik (LG. 13). ${ }^{73}$ Dengan begitu dinamika antara iman dan budaya bukan sekadar usaha penanaman Gereja di kebudayaan lain tetapi merupakan relasi resiprokal yang menghasilkan transformasi baru. Dengan kata lain, sebagai man of the church lewat inkulturasinya menurut penulis Prier telah melakukan dua hal sekaligus yakni (1) membumikan yang global secara lokal (holding the global locally) sekaligus (2) mempromosikan yang lokal secara global (promoting the local globally).

\section{PENUTUP}

Kita menyadari bahwa Gereja Indonesia memiliki residu hegemoni budaya Barat. Tetapi Konsili Vatikan II telah membawa semangat aggiornamento. Isu bahwa budaya Gereja menjajah budaya setempat dan extra ecclesiam nulla salus telah dihilangkan. Dengan semboyan ecclesia semper reformanda Gereja menunjukkan penghargaannya terhadap kelokalan. Musik inkulturasi sebagai musik peribadatan pun muncul sebagai musik alternatif selain musik Gregorian.

Dalam proses inkulturasi, seperti yang terjadi dalam inkulturasi Prier, penulis belajar bahwa inkulturasi menuntut kerja kolaboratif. Dengan begitu lebih dari sekadar proses adaptasi, inkulturasi merupakan proses pemribumian ekspresi iman Kristiani lewat gerak ganda yakni (1) kekristenan yang mengakarkan diri ke budaya setempat sekaligus (2) integrasi budaya setempat ke kekristenan. Dua gerak dinamis ini menghasilkan transformasi budaya dan regenerasi nilai kultural. ${ }^{74}$ Tanpa proses tersebut hanya akan menghasilkan drama budaya seperti diungkapkan oleh Paus Paulus VI (EN 20). Kesatuan kristiani yang hanya sebatas penyeragaman budaya tidak akan menyentuh ke sanubari umat setempat.

Hubungan iman dan budaya dalam inkulturasi hendaknya seperti peristiwa paskah dalam misteri hidup Kristus. Dalam arti tertentu inkulturasi adalah peristiwa meninggalkan menara Babel menuju ke peristiwa pentekosta, tidak malahan kembali ke situasi Babel di mana seluruh dunia hanya memiliki satu bahasa saja (Kej. 11:1). Untuk itu dalam kesadaran postkolonialisme, janganlah gerakan inkulturasi berbalik menjadi gerakan occidentalisme. Inkulturasi jangan berhenti pada tren pada masa lalu saja. Inkulturasi merupakan tindakan yang berkesinambungan (on going process).

Maka, jika Ary Roest Crollius menunjukkan bahwa 'enkulturasi' dalam konsep antropologi merupakan proses yang tidak terbatas pada masa balita tetapi dilanjutkan seumur hidup, kiranya demikian halnya dengan inkulturasi Gereja. Hendaknya in- 
kulturasi tidak hanya dilakukan Gereja pada saat awal masuk ke dalam suatu budaya saja tetapi diteruskan pada setiap situasi baru yang dihadapinya. Apalagi budaya merupakan entitas yang dinamis berubah terus menerus. Dengan demikian tugas evangelisasi budaya seharusnya tidak berhenti untuk Gereja muda saja tetapi dilakukan hingga saat ini.

\section{CATATAN AKHIR}

1 Wawancara dengan Prier 17 Februari 2017, pukul 17.28. Budi Subanar juga menunjukkan bahwa lagu "Nata Agung" digunakan untuk menyambut Presiden Soekarno saat memasuki Kampus PTPG (Perguruan Tinggi Pendidikan Guru) Sanata Dharma. Ekspresi ruang publik sekular tersebut kemudian diambilalih di dalam ekspresi liturgi. Budi Subanar, "Membaca Ulang Ekspresi (Publik) Di Dalam Lingkup Gerejawi," dalam Dilema Identitas: Beragama vs Bernegara? Fenomena Vol. VIII/No. 1 (2011): 10.

2 Menurut Budi Subanar, stereotipe kekristenan sebagai antek kolonial sengaja dimunculkan oleh pihak Jepang untuk menyerang Kolonial Barat.

3 Michael Paul Gallagher, Clashing Symbols: An Introduction to Faith and Culture (London: Darton Longman Tood Ltd., 1997).

4 Theoneste Nkeramihigo, "Inculturation and Specificity of Christian Faith", dalam Ary Roest Crollius, What Is So New About Inculturation?, Inculturation Working Papers on Living Faith and Cultures (Roma: Pontificia Universita Gregoriana, 1991), 23-26.

5 Edward Said, Orientalism (London: Routledge \& Kegan Paul Ltd., 1978), 2-3.

6 R.S. Sugirtharajah, The Postcolonial Biblical Reader (Oxford: Willey Blackwell, 2005), 21.

7 Homi K. Bhabha, The Location of Culture, 35.

8 Istilah liminalitas berasal dari kata 'limen', yang berarti ambang batas. Dalam teori postkolonial digunakan untuk menggambarkan ruang antara (in-between space) di mana perubahan budaya dapat terjadi atau ruang transkultural di mana ada proses pertukaran budaya antar negara yang berbeda. Misalnya, subjek yang dijajah bisa tinggal di ruang liminal antara wacana kolonial dan asumsi identitas 'non-kolonial' baru. Homi Bhabha mengutip sejarawan Renée Green yang menggambarkan anak tangga sebagai 'ruang liminal'. Jalur antara daerah atas dan bawah digambarkan sebagai ruang liminal. Liminal bisa menjadi ruang interaksi simbolis. Artinya, gambaran antara anak tangga atau liminal mencegah polarisasi identitas antara sebutan sewenang-wenang seperti 'atas' dan 'rendah', 'hitam' dan 'putih' Bill Ashcroft, Gareth Griffiths dan Helen Tiffin, Postcolonial Studies: The Key Concepts, 3rd edition, 145.

9 Saat itu istilah inkulturasi belum populer dipergunakan. Dalam istilah teologis lebih banyak digunakan istilah adaptasi dan akomodasi (incorporative accomodation). Hardawiryana "Building the Church of Christ in Pluricultural Situation", dalam Roest Crollius, Building The Church in Pluricultural Asia, Inculturation Working Papers on Living Faith and Cultures VII (Rome: Pontifical Gregorian University, 1986), 3

10 Martasudjita, Pengantar Liturgi: Makna, Sejarah dan Teologi Liturgi (Yogyakarta: Kanisius, 1999), 81.

11 Th. Van den End, Ragi Carita I-Sejarah Gereja di Indonesia 1500-1860 (Jakarta: BPK Gunung Mulia, 2001), 24

12 D. S. Amalorpavadaas, "Injil dan Kebudayaan: Evangelisasi dan Inkulturasi” dalam G. Kirchbreger (ed.), Gereja Berwajah Asia (Ende: Nusa Indah, 1995), 89.

13 Robertus Wijanarko, "Poskolonialisme dan Studi Teologi," dalam Studia Philosophica et Theologica 8 (2008): 125.

14 Antonius Marius Tangi, "Inkulturasi Liturgi" dalam Komisi Liturgi KWI, Liturgi Selalu Diperbaharui (Jakarta: Mitra Komisi Liturgi KWI, 2015), 84

15 Hardawiryana, "Building the Church of Christ in Pluricultural Situation" dalam Roest Crollius, Building The Church in Pluricultural Asia Inculturation Working Papers on Living Faith and Cultures VII (Rome: Pontifical Gregorian University, 1986), 4.

16 Herve Carrier, Evangelizing the Culture of Modernity (Maryknoll: Orbis Books, 1993), 1-5.

17 Adolf Heuken. 150 Tahun Serikat Jesus Berkarya di Indonesia (Jakarta: Cipta Loka Caraka, 2009), 13.

18 Michael Paul Gallagher, Clashing Symbols: An Introduction to Faith \& Culture, 108.

19 Paulo Castagna, "The Use of Music by the Jesuits in the Conversion of the Indigeneous Peoples of Brazil" dalam John O'Malley, Gauvin Bailey, (ed.), The Jesuits, Cultures, Sciences and The Arts 1540-1773 (Canada: University of Toronto Press, 2000), 641-658.

20 William J. Summers. "The Jesuits and Music in Manila, 1581-1621" dalam John O'Malley, S.J., Gauvin Bailey, (ed.), The Jesuits, Cultures, Sciences and The Arts 1540-1773 (Canada: University of Toronto Press, 2000), 641-658.

21 Harsi dan Gunarto, Mengenal Sosok C. Hardjasoebrata: Seniman yang Tidak suka Disebut Seniman, 101-102.

22 "Rasane ora sreg, lagune cara landa koq tembunge basa Jawa. Apa ora bisa yen lagune uga cara Jawa" (rasanya tidak enak, musiknya Belanda tetapi katakatanya dalam bahasa Jawa. Apakah tidak bisa kalau musiknya juga Jawa?)

23 St. Sunardi, "Lagune Cara Landa Kok Tembunge Basa Jawa" dalam Vodka dan Birahi Seorang Nabi: EsaiEsai Seni dan Estetika, 387. Hal ini bisa dicermati juga dalam surat-surat Bruder Clementinus kepada Hardjasoebrata. 
24 G. Subanar, S.J., "Pergulatan Gereja dalam Perjumpaan dengan Budaya-Budaya Setempat di Era Globalisasi" (Makalah mata kuliah Misi dan Dialog, Universitas Sanata Dharma), 4.

25 Lih. Karl-Edmund Prier, Perjalanan Musik Gereja Katolik Indonesia Tahun 1957-2007 (Yogyakarta, Pusat Musik Liturgi, 2008), 7.

26 Diatonis (diatonicus) adalah aturan nada yang terdiri dari tujuh jenis bunyi dengan titi nada do, re, mi, fa, sol, la, si. Sedangkan pentatonis (pentetonicus) adalah aturan nada dengan lima jenis bunyi. Gamelan Jawa asli biasanya bertangga nada pentatonis. Baik itu Slendro: 1 (ji), 2 (ro), 3 (lu), 5 (mo), 6 (nem). Maupun Pelog: 1 (ji), 3 (lu), 4 (pat), 5 (mo), 7 (pi).

27 Nugroho, "Gamelan Supra (Sugijapranata): Musik Pendidikan Humanisme Ignatian”, 163-165.

28 Bonefasius Jehandut, Uskup Wilhelmus van Bekkum E Dere Serani, 70-73.

29 Dr. Huub J.W.M. Boelaars, Indonesianisasi: Dari Gereja Katolik di Indonesia Menjadi Gereja Katolik Indonesia (Yogyakarta: Kanisius, 2005), 426-427.

30 Jika ada misionaris yang tidak terpengaruh gaya berpikir semacam ini, mungkin adalah misionaris yang mengusung gagasan humanisme ignatian. Tetapi debat yang muncul, bukankah humanisme ignatian yang dipahami di abad-abad XVII, XVIII atau XIX masih terpengaruh superioritas gaya berpikir barat. Yang jelas, para misionaris yang mengusung humanisme ignatian adalah entitas yang cukup berbeda dengan cara berpikir misionaris era kolonial.

31 Paul G. Hiebert, Anthropological Reflections on Missiological Issues (Michigan: Baker Books, 1994), 53-55.

32 Satu-satunya dasar rasional yang bisa digunakan untuk memilih teori adalah berkaitan dengan kegunaan dengan hidup kita. Paul G. Hiebert. Anthropological Reflections on Missiological Issues (Michigan: Baker Books, 1994), 58-63.

33 Hiebert menyebutkan salah seorang sejarawan yang telah mencoba melihat misi dari perseptif global adalah Lamin O. Sanneh, Translating the Message: The Missionary Impact on Culture (New York: Orbis, 1989).

34 Selama periode kolonial kelompok ini telah ada, tetapi karena memiliki satu musuh bersama yakni para penjajah, mereka berusaha mengesampingkan perbedaan mereka. Setelah kemerdekaan, Soekarno berusaha menyatukan itu lewat Pancasila. Lewat konsep Pancasila, Soekarno (presiden pertama Indonesia) mencoba menggabungkan sosialisme, nasionalisme, monoteisme. Pancasila dijadikan sebagai pemersatu semua ideologi di Indonesia. Soeharto (presiden kedua Indonesia) kemudian menggunakan konsep Pancasila untuk menekan yang bertentangan dengan dia. Satu-satunya kelompok yang keberatan dengan konsep sila pertama Pancasila disebut Soekarno sebagai kelompok Muslim Ortodoks. Mereka ingin agar Syariat Islam dimasukkan dalam Pancasila.
35 Tulisan panjang artikel ini berjudul "Indonesianisasi dan Occidentalisasi Gereja Katolik" di majalah Hidup XXV no.13, tanggal 14 April (1971). Lih. juga, F.X Danuwinata S.J., "Indonesianisasi dan Imamat" dalam Spektrum 4 (1971), 47-49.

36 Karel Steenbrink, "The Power of Money: Development Aid For and Through Christian Churches in Modern Indonesia, 1965-1980" dalam Susanne Schroter (ed.), Christianity in Indonesia: Perspective of Power (Berlin: Lit Verlag, 2010), 105-108.

37 Karel Steenbrink, "The Power of Money: Development Aid For and Through Christian Churches in Modern Indonesia, 1965-1980" dalam Susanne Schroter (ed.), Christianity in Indonesia: Perspective of Power, 130132

38 Spektrum, "Indonesianisasi", 5-11.

39 Spektrum, "Indonesianisasi", 15-27.

40 Vocalista Sonora didirikan Paul Widyawan pada tahun 1964 dan bernaung di bawah Pusat Kateketik (Puskat) Yogyakarta. Kedekatan teritorial ini membuat Frater Prier sering bertemu dengan Paul Widyawan.

41 Prier, Perjalanan Musik Gereja Katolik Indonesia Tahun 1957-2007, 17.

42 Kompas, 27 Juni 1983, Dr. Huub J.W.M. Boelaars, Indonesianisasi: Dari Gereja Katolik di Indonesia Menjadi Gereja Katolik Indonesia, 429.

43 Karl Edmund Prier, Perjalanan Musik Gereja Katolik Indonesia Tahun 1957-2007, 38.

44 Karl Edmund Prier, Perjalanan Musik Gereja Katolik Indonesia Tahun 1957-2007, 32-39.

45 Pusat Musik Liturgi, "Program dan Daftar Terbitan 1983/1984” booklet (Yogyakarta: Pusat Musik Liturgi, 1984), 1-2.

46 Richard Friedli, "Intercultural Theology," dalam Karl Müller et al. (eds.), Dictionary of Mission (Maryknoll, New York: Orbis Books, 1997), 219-222.

47 Dokumen Konsili Vatikan II merefleksikan tema-tema seperti keberadaan Gereja di dunia (Gaudium et Spes), ekumenisme (Unitatis Redintegratio), aktivitas misionaris (ad Gentes) dan relasi Gereja dengan umat agama lain (Nostra Aetate). Bdk. John D. Dadosky, "Towards a Fundamental Reinterpretation of Vatican II," Heythrop Journal, 49 September (2008), 742-763.

48 Bisa dilihat juga Karl Rahner, "Towards a Fundamental Theological Interpretation of Vatican II,” Theological Studies 40 (1979), 716.

49 Dialog antara Iman dan budaya dibicarakan Paus di Universitas Sogang di Seoul 5 Mei 1985. Teks asli di Origins Vol. 14. No. 2. 24 Mei, (1984), 2.

50 John W. O'Malley, dkk. (ed.), The Jesuits: Cultures, Sciences, and The Arts, 1540-1773 (Canada: University of Toronto Press, 2000), xiii.

51 Gagasan agung ini membuat mereka aktif menyebarkan kekristenan. Bahkan bagi Yesuit seluruh dunia ini digambarkan sebagai medan pertempuran antara mereka yang mengikuti Yesus dan Setan. Yesus mengajak semua orang menjadi muridNya (Mat. 9: $37-$ 10:15). Oleh sebab itu misi Serikat Yesus bercorak universal. John W. O'Malley, dkk. (ed.), The Jesuits: Cultures, Sciences, and The Arts, 1540-1773, 4-16. 
52 Adolf Heuken. 150 Tahun Serikat Jesus Berkarya di Indonesia (Jakarta: Cipta Loka Caraka, 2009), 12-13.

53 Ecclesia ad intra biasanya mengarah kepada dokumen Lumen Gentium. Sedangkan Ecclesia ad extra mengarah kepada dokumen Gaudium et Spes.

54 Susanne Schroter (ed.), Christianity in Indonesia: Perspective of Power, 13.

55 Dr. Huub J.W.M. Boelaars, Indonesianisasi: Dari Gereja Katolik di Indonesia Menjadi Gereja Katolik Indonesia, 93.

56 Oleh sebab itu Prier sebagai orang Jerman menjadi misionaris di Indonesia. Bdk. Robert Hardawiryana, Umat Kristiani Mempribumi Menghayati Iman Kristiani di Nusantara, 61.

57 Emanuel Subangun, Dekolonisasi Gereja di Indonesia (Yogyakarta: Kanisius, 2003), 85.

58 Bdk Muskens, (1969), hlm. 240-241, Huub J.W.M. Boelaars, OFM Cap. Indonesianisasi, Dari Gereja Katolik di Indonesia Menjadi Gereja Katolik Indonesia (Yogyakarta: Kanisius, 2005), 145-149.

59 Bdk Muskens, (1969), hlm. 240-241, Huub J.W.M. Boelaars, OFM Cap. Indonesianisasi, Dari Gereja Katolik di Indonesia Menjadi Gereja Katolik Indonesia (Yogyakarta: Kanisius, 2005), 145-149.

60 Karl Edmund Prier, Roda Musik, 54-56.

61 Robert J. Schreiter, The New Catholicity: Theology between the Global and the Local, 26.

62 Homogenisasi budaya adalah penyatuan pelbagai macam budaya. Hal ini seolah menimbulkan penyeragaman budaya, Craig Ott dan Harold A. Netland (eds), Globalizing Theology: Belief and Practice in an Era of World Christianity (Michigan: Baker Academic, 2006), 101.

63 Nesto Gracia, Hybrid Cultures: Strategies for Entering and Leaving Modernity (Minneapolis: University of Minnesota Press, 1995), 12-16.

64 Pieris terinspirasi oleh Schillebeeckx yang berpendapat bahwa pembaptisan Yesus oleh Yohanes menjadi isyarat kenabian. Ketertundukan Yesus yang rendah hati pada pembaptisan Yohanes betapapun memalukan bagi umat Kristiani awal tetapi juga memunculkan otoritasnya untuk memproklamirkan Kerajaan Allah. Ungkapan "Dengarkanlah Dia" menjadi klaim profetis sekaligus mandat perutusan di hadapan banyak orang. Aloysius Pieris, An Asian Theology of Liberation (Philippines: Claretian Publication, 1996), 83-85.

65 Dalam praktiknya, selalu terjadi tarik ulur, Gereja lokal Barat di Asia tampaknya juga takut terhadap tantangan identitas Kristiani ini. Ketakutan ini bersumber dari perasaan masa lampau yang sudah jelas dan masa depan yang tidak jelas. Gereja lokal 'di' Indonesia terbukti sudah jelas sedangkan Gereja lokal 'dari' Indonesia belum terwujud.

66 Redaksi, "Musik Tradisional Indonesia" Warta Musik, no. 2/XXII (1997), 60.

67 Karl Edmund Prier, Perjalanan Musik Gereja Tahun 1957-1977, 41.

68 Philip Yampolsky, "Hati Yang Luka: An Indonesian Hit" dalam Indonesia, volume 47 April (1989), 6.
69 Michael HB Raditya, "Ketika Bung Karno Melarang Dangdut" dalam Jurnal Ruang (01 September 2017), https://jurnalruang.com/read/1504165648-ketikabung-karno-melarang-dangdut diakses 5 Oktober 2017 pukul 19.45 .

70 Ki Hadjar Dewantara menjelaskan bahwa puncak dan sari kebudayaan yang terdapat di kepulauan Indonesia baik lama atau baru yang berjiwa nasional itulah kebudayaan nasional. Puncak dan sari, bukan berarti dikumpulkan menjadi satu lalu dipakai seluruh orang Indonesia semisal, memakai ikat kepala blangkon, baju minang, sarung setengah dilipat, celana hitam memanjang dan sepatu setengah sandal. Bukan pula berarti kesenian dari Sulawesi, Sumatra harus dipelajari orang yang bukan berasal dari daerahnya sendiri. Ki Hajar Dewantara menegaskan bahwa kebudayaan nasional itu berarti mengolah pelbagai kebudayaan menjadi kebudayaan yang baru. Ki Suratman, "Puncak-Puncak yang menimbulkan Persepsi Kebudayaan Nasional", dalam Moedjanto (ed). Tantangan Kemanusiaan Universal (Yogyakarta: Kanisius, 1992), 168.

71 "The Christian Conference of Asia" CCA News 15 June (1980), 6 .

72 Justine George, Intercultural Theology: An Approach of Theologizing in the context of Pluralism and Globalization, 28.

73 Justine George, Intercultural Theology: An Approach of Theologizing in the context of Pluralism and Globalization, 37.

74 Ary Roest Crollius, Creative Inculturation and The Unity of Faith dalam Inculturation working Papers on Living Faith and Cultures (Roma: Pontifical Gregorian University, 1986), 3-4.

\section{DAFTAR RUJUKAN}

\section{........., Origins Vol. 14. No. 2. 24 Mei, 1984}

Ashcroft, Bill, Gareth Griffiths dan Helen Tiffin. Postcolonial Studies: The Key Concepts, 3rd edition. New York: Routledge, 2013.

Azevedo, Marcello de Calvalho. S.J. "Inculturation and The Challenges of Modernity", dalam Ary A. Roest Crollius, S.J. (ed.) Inculturation and The Challenges of Modernity, Inculturation Working on Living Faith and Cultures. Rome: Pontifical Gregorian University, 1982.

Bhabha, Homi K. The Location of Culture. London: Routledge, 1994. 
Boelaars, Huub J.W. M. OFM Cap., Indonesianisasi: Dari Gereja Katolik di Indonesia Menjadi Gereja Katolik Indonesia. Yogyakarta: Kanisius, 2005.

Carrier, Herve. S.J. Evangelizing the Culture of Modernity. Maryknoll: Orbis Books, 1993.

Castagna, Paulo. "The Use of Music by the Jesuits in the Conversion of the Indigeneous Peoples of Brazil" dalam John O'Malley, S.J., Gauvin Bailey, (ed.) The Jesuits, Cultures, Sciences and The Arts 1540-1773. Canada: University of Toronto Press, 2000.

Crollius, Ary A. Roest. S.J. "What Is So New about Inculturation?" dalam What Is So New about Inculturation? Seri Inculturation, Working Papers on Living Faith and Cultures, V. Rome: Pontifical Gregorian University1984,.

Crollius, Ary Roest. S.J. "Creative Inculturation and The Unity of Faith", dalam Inculturation working Papers on Living Faith and Cultures. Roma: Pontifical Gregorian University, 1986.

Dadosky, John D. "Towards a Fundamental Reinterpretation of Vatican II," dalam Heythrop Journal, 9 September 2008.

Danuwinata F.X. S.J. "Indonesianisasi dan Imamat” dalam Spektrum 4 (1971).

den End, Th. Van. Ragi Carita I-Sejarah Gereja di Indonesia 1500-1860. Jakarta: BPK Gunung Mulia, 2001.

Dewantara, Ki Hajar. "Tentang PuntjakPuntjak dan Sari-Sari Kebudajaan di Indonesia" dalam Moedjanto (ed.). Tantangan Kemanusiaan Universal. Yogyakarta: Kanisius, 1992.

Friedli, Richard. "Intercultural Theology," dalam Karl Müller et al. (eds.), Dictionary of Mission. Maryknoll New York: Orbis Books, 1997.
Gallagher, Michael Paul. S.J. Clashing Symbols: An Introduction to Faith and Culture. London: Darton Longman Tood Ltd, 1997,

George, Justine. Intercultural Theology: An Approach of Theologizing in the context of Pluralism and Globalization (ThM/STL. tesis tidak dipublikasikan. Toronto: Toronto School of Theology, 2012).

Gracia, Nesto. Hybrid Cultures: Strategies for Entering and Leaving Modernity. Minneapolis: University of Minnesota Press, 1995.

Hardawiryana, Robertus. S.J. "Building the Church of Christ in Pluricultural Situation" dalam Roest Crollius, S.J. Building The Church in Pluricultural Asia, Inculturation Working Papers on Living Faith and Cultures VII. Rome: Pontifical Gregorian University, 1986.

Hardjasoebrata, C. Kula Sowan Gusti. Yogyakarta: Pusat Musik Liturgi, 1987.

Harsi dan Gunarto. Mengenal Sosok C. Hardjasoebrata: Seniman yang Tidak suka Disebut Seniman. Yogyakarta: Indie Book Corner, 2015.

Heuken, Adolf. Ensiklopedi Gereja, Jilid 1. Jakarta: Yayasan Cipta Loka Caraka, 1994.

Heuken, Adolf. Ensiklopedi Gereja, Jilid IV. Jakarta: Yayasan Cipta Loka Caraka, 2004.

Heuken, Adolf. $\quad 150$ Tahun Serikat Jesus Berkarya di Indonesia. Jakarta: Cipta Loka Caraka, 2009.

Hiebert, Paul G. Anthropological Reflections on Missiological Issues. Michigan: Baker Books, 1994.

Huddart, David. Homi K. Bhabha. New York: Routledge, 2006. 
Jehandut, Bonefasius. Uskup Wilhelmus van Bekkum \& Dere Serani. Jakarta: Nera Pustaka, 2012.

Kirchberger, Georg (ed.). Gereja berwajah Asia. Ende: Nusa Indah, 1995.

Lechovic, V. Tsi Tanaeb Uis Neno (Kitab Nyanyian Bahasa Dawan). Ende: Percetakan Arnoldus, 1957.

Martasudjita, Pr. Pengantar Liturgi: Makna, Sejarah dan Teologi Liturgi. Yogyakarta: Kanisius, 1999.

Nkeramihigo, Theoneste, S.J. "Inculturation and Specificity of Christian Faith" dalam Ary Roest Crollius, S.J. What Is So New About Inculturation?, Inculturation Working Papers on Living Faith and Cultures. Roma: Pontificia Universita Gregoriana, 1991.

Nugroho. "Gamelan Supra (Sugijapranata): Musik Pendidikan Humanisme Ignatian" (M.Hum. tesis tidak dipublikasikan. Yogyakarta: Universitas Sanata Dharma, 2008).

O'Malley, S.J., John W. dkk. (ed.) The Jesuits: Cultures, Sciences, and The Arts, 1540-1773. Canada: University of Toronto Press, 2000.

Pieris, Aloysius. An Asian Theology of Liberation. Philippines: Claretian Publication, 1996.

Prier, Karl Edmund S.J. dan Paul Widyawan. Roda Musik Liturgi: Panduan untuk Para Petugas Liturgi. Yogyakarta: Pusat Musik Liturgi, 2012.

Prier, Karl Edmund, S.J. Sejarah Musik Jilid 1. Yogyakarta: Pusat Musik Liturgi, 1991.

Prier, Karl Edmund, S.J. Sejarah Musik Jilid 2. Yogyakarta: Pusat Musik Liturgi, 1993.
Prier, Karl Edmund, S.J. Inkulturasi Musik Liturgi. Yogyakarta: Pusat Musik Liturgi, 1999.

Prier, Karl Edmund, S.J. Perjalanan Musik Gereja Katolik Indonesia Tahun 19572007. Yogyakarta, Pusat Musik Liturgi, 2008.

Prier, Karl Edmund, S.J. Inkulturasi Nyanyian Liturgi, PML A-45. Yogyakarta: Pusat Musik Liturgi, 1986.

Raditya, Michael HB. "Ketika Bung Karno Melarang Dangdut", dalam Jurnal Ruang (01 September 2017), https://jurnalruang.com/read/1504165 648-ketika-bung-karno-melarangdangdut diakses 5 Oktober 2017 pukul 19.45 .

Rahner, Karl. "Towards a Fundamental Theological Interpretation of Vatican II,” Theological Studies 40 (1979).

Said, Edward. Orientalism. London: Routledge \& Kegan Paul Ltd, 1978.

Schreiter, Robert J. The New Catholicity: Theology between the Global and the Local, Maryknoll. New York: Orbis Books, 1997.

Schroter, Susanne (ed.) Christianity in Indonesia: Perspective of Power. Berlin: Lit Verlag, 2010.

Steenbrink, Karel. "The Power of Money: Development Aid For and Through Christian Churches in Modern Indonesia, 1965-1980" dalam Susanne Schroter (ed.) Christianity in Indonesia: Perspective of Power. Berlin: Lit Verlag, 2010.

Subanar, Budi. "Membaca Ulang Ekspresi (Publik) Di Dalam Lingkup Gerejawi", dalam Dilema Identitas: Beragama vs Bernegara? Fenomena Vol. VIII/No. 1 (2011). 
Subangun, Emanuel. Dekolonisasi Gereja di Indonesia. Yogyakarta: Kanisius, 2003.

Sugirtharajah, R.S. The Postcolonial Biblical Reader, Oxford: Willey Blackwell, 2005.

Sugirtharajah, R.S. Postcolonial Reconfiguration: An Alternative Way of Reading the Bible and Doing Theology. St Louis: Chalice Press, 2003.

Summers, William J. "The Jesuits and Music in Manila, 1581-1621" dalam John O’Malley, S.J. Gauvin Bailey, (ed.) The Jesuits, Cultures, Sciences and The Arts 1540-1773. Canada: University of Toronto Press, 2000.
Sunardi, St. Vodka dan Birahi Seorang Nabi: Esai-Esai Seni dan Estetika. Yogyakarta: Jalasutra, 2012.

Suratman. "Puncak-Puncak yang menimbulkan Persepsi Kebudayaan Nasional" dalam Moedjanto (ed) Tantangan Kemanusiaan Universal. Yogyakarta: Kanisius, 1992.

Wijanarko, Robertus. "Poskolonialisme dan Studi Teologi" dalam Studia Philosophica et Theologica, Vol. 8 No.2 Oktober 2008 (2008).

Yampolsky, Philip. "Hati Yang Luka: An Indonesian Hit" dalam Indonesia, volume 47 April 1989(1989). 
